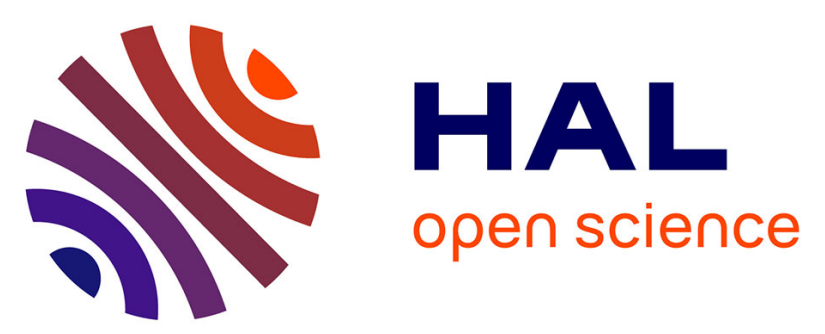

\title{
A Naturally Occurring Human Minidysferlin Protein Repairs Sarcolemmal Lesions in a Mouse Model of Dysferlinopathy
}

\author{
Martin Krahn, Nicolas Wein, Marc Bartoli, William Lostal, Sebastien \\ Courrier, Nathalie Bourg-Alibert, Karine Nguyen, Christophe Vial, Nathalie \\ Streichenberger, Veronique Labelle, et al.
}

\section{To cite this version:}

Martin Krahn, Nicolas Wein, Marc Bartoli, William Lostal, Sebastien Courrier, et al.. A Naturally Occurring Human Minidysferlin Protein Repairs Sarcolemmal Lesions in a Mouse Model of Dysferlinopathy. Science Translational Medicine, 2010, 2 (50), 10.1126/scitranslmed.3000951 . hal-01610037

\section{HAL Id: hal-01610037 \\ https://hal.science/hal-01610037}

Submitted on 13 Dec 2017

HAL is a multi-disciplinary open access archive for the deposit and dissemination of scientific research documents, whether they are published or not. The documents may come from teaching and research institutions in France or abroad, or from public or private research centers.
L'archive ouverte pluridisciplinaire HAL, est destinée au dépôt et à la diffusion de documents scientifiques de niveau recherche, publiés ou non, émanant des établissements d'enseignement et de recherche français ou étrangers, des laboratoires publics ou privés. 


\title{
A Naturally Occurring Human Minidysferlin Protein Repairs Sarcolemmal Lesions in a Mouse Model of Dysferlinopathy
}

\author{
Martin Krahn, ${ }^{1,2 *}$ Nicolas Wein, ${ }^{1 *}$ Marc Bartoli, ${ }^{1,3 *}$ William Lostal, ${ }^{3}$ Sébastien Courrier, ${ }^{1}$ \\ Nathalie Bourg-Alibert, ${ }^{3}$ Karine Nguyen, ${ }^{1,2}$ Christophe Vial, ${ }^{4}$ Nathalie Streichenberger, ${ }^{5}$ \\ Véronique Labelle, ${ }^{2}$ Danielle DePetris, ${ }^{1}$ Christophe Pécheux, ${ }^{2}$ France Leturcq, ${ }^{6}$ Pierre Cau, ${ }^{1}$ \\ Isabelle Richard, ${ }^{3}$ Nicolas Lévy, ${ }^{1,2 \dagger}$ \\ (Published 22 September 2010; Volume 2 Issue 50 50ra69)
}

\begin{abstract}
Dysferlinopathies are autosomal recessive, progressive muscle dystrophies caused by mutations in DYSF, leading to a loss or a severe reduction of dysferlin, a key protein in sarcolemmal repair. Currently, no etiological treatment is available for patients affected with dysferlinopathy. As for other muscular dystrophies, gene therapy approaches based on recombinant adeno-associated virus (rAAV) vectors are promising options. However, because dysferlin messenger RNA is far above the natural packaging size of rAAV, full-length dysferlin gene transfer would be problematic. In a patient presenting with a late-onset moderate dysferlinopathy, we identified a large homozygous deletion, leading to the production of a natural "minidysferlin" protein. Using rAAV-mediated gene transfer into muscle, we demonstrated targeting of the minidysferlin to the muscle membrane and efficient repair of sarcolemmal lesions in a mouse model of dysferlinopathy. Thus, as previously demonstrated in the case of dystrophin, a deletion mutant of the dysferlin gene is also functional, suggesting that dysferlin's structure is modular. This minidysferlin protein could be used as part of a therapeutic strategy for patients affected with dysferlinopathies.
\end{abstract}

\section{INTRODUCTION}

Mutations in the gene encoding dysferlin [DYSF; Mendelian Inheritance in Man (MIM) 603009, 2p13, GenBank NM_003494.2] cause limb girdle muscular dystrophy type 2B (LGMD2B; MIM 253601) (1) and Miyoshi myopathy (MM; MIM 254130) (2). These diseases are characterized by progressive muscle weakness, usually appearing in the second decade, and highly elevated serum creatine kinase (CK) concentrations. Moreover, mutations in DYSF cause a wide spectrum of phenotypes, ranging from clinically asymptomatic, isolated hyperCKemia to severe and early-onset presentations (1-5). The dystrophic process is caused by the absence or severe reduction of dysferlin, a $237-\mathrm{kD}$ plasma membrane protein (6), which plays a central role in sarcolemmal repair (7). Dysferlin is mainly expressed in skeletal and heart muscles, placenta, and monocytes/macrophages (8-11). Dysferlin has a long N-terminal cytosolic domain, with seven predicted C2 domains known to be involved in calcium and phospholipid binding, and a C-terminal transmembrane (TM) domain followed by a short extracellular domain $(12,13) . D Y S F$ has a large mutational spectrum including mainly point mutations and small-sized nucleotide insertions/deletions (14-18). Only recently, different genomic rearrangements have also been shown to be possible DYSF disease-causing mutations (19).

1'Inserm UMR_S 910, "Génétique Médicale et Génomique Fonctionnelle," Faculté de Médecine de Marseille, Université de la Méditerranée, 13005 Marseille, France. ²Département de Génétique Médicale, Hôpital d'Enfants de la Timone, AP-HM, 13005 Marseille, France. ${ }^{3}$ Généthon, CNRS UMR8587 LAMBE, 91001 Evry, France. ${ }^{4}$ Hôpital neurologique Pierre Wertheimer, 69500 Lyon, France. ${ }^{5}$ Service de neuropathologie, hôpital neurologique, CHU de Lyon, 69500 Lyon, France. ' Laboratoire de Biochimie Génétique, Hôpital Cochin, AP-HP, 75014 Paris, France.

*These authors contributed equally to this work.

†To whom correspondence should be addressed. E-mail: nicolas.levy@univmed.fr
Currently, no etiological treatment is available for patients affected with dysferlinopathy. As for other muscular dystrophies, gene therapy approaches based on adeno-associated virus (AAV)-derived vectors have been considered as possible options. However, the large size of the DYSF gene hampers direct transfer of the entire complementary DNA (cDNA) with regard to the limited AAV packaging size, and alternative strategies are required (20). Indeed, full-length dysferlin gene transfer was successfully achieved by AAV concatemerization (21). In the case of dystrophin, another large gene, different strategies have been developed as an alternative to recombinant AAV (rAAV) whole-gene transfer (22-24). Indeed, association of mild clinical presentations with in-frame truncated forms of dystrophin led to the development of therapeutic strategies, mainly gene transfer of functional "minidystrophin" or exon-skipping approaches (25). The necessary prerequisite of these approaches is that part of the amino acid sequence can be deleted without major impact on the overall function of the protein. Thus, identifying naturally occurring deletion mutants from genomic explorations in patients affected with muscular dystrophies is a pertinent strategy. A systematic search of disease-associated singleor multiple-exon in-frame deletions, in patients presenting mild phenotypes, should enable the identification of dispensable coding regions, allowing the development of "minigene" or exon-skipping therapeutic approaches.

In this context, we report a proof of principle for a minigene approach for dysferlinopathies. In a female patient (F1-26-1-2) presenting with a late-onset and moderate dysferlinopathy, we identified a homozygous genomic multiexonic internal deletion of the dysferlin gene. This clinical observation appeared as a unique natural case to analyze a minimal functional structure of the dysferlin protein and thus to evaluate whether "minidysferlin" or exon-skipping approaches could be developed for dysferlinopathies. 


\section{RESULTS}

\section{Identification of a minidysferlin protein in a patient}

Patient F1-26-1-2 was born to distantly consanguineous parents. At the age of 30 years, she noticed proximal weakness with difficulty climbing stairs and running and presented highly elevated serum CK concentrations (2000 to 4000 IU/liter; normal <200 IU/liter). A muscle needle biopsy was initially performed and demonstrated mild aspecific dystrophic pattern (Fig. 1A). Multiplex immunoblot analyses demonstrated total absence of the typical $237-\mathrm{kD}$ band corresponding to full-length dysferlin, without secondary calpain-3 deficiency (Fig. 1B, lane 2). Currently, at the age of 44 years, she presents with walking difficulties, but is still ambulant without a cane. Clinical examination showed atrophy of the calves and weakness affecting selectively the quadriceps muscles of the thighs, consistent with an MM phenotype.

On the basis of this clinical presentation, the patient was included for DYSF mutation analysis as previously described (18). Polymerase chain reaction (PCR) with primers for the amplification of DYSF coding exons and flanking intronic boundaries failed to amplify exons 2 to 40 on the DNA of the patient. We thus hypothesized the existence of a large genomic deletion. Using an oligonucleotide-based comparative genomic hybridization (CGH) array for high-throughput detection of exonic deletions or duplications in DYSF (Fig. 2A), we identified a homozygous internal deletion encompassing exons 2 to 40 . Genomic quantitative PCR with a TaqMan probe located in exon 30 of DYSF confirmed the presence of a genomic deletion at a homozygous state for the patient and a heterozygous state for her parents (fig. S1A). On the basis of the CGH array findings, we selected primers for long-range PCR to determine the genomic borders/breakpoints. A 3952-base-pair (bp) junction fragment was first obtained in the patient and her parents, with a forward primer located in intron 1 and a reverse primer located

A

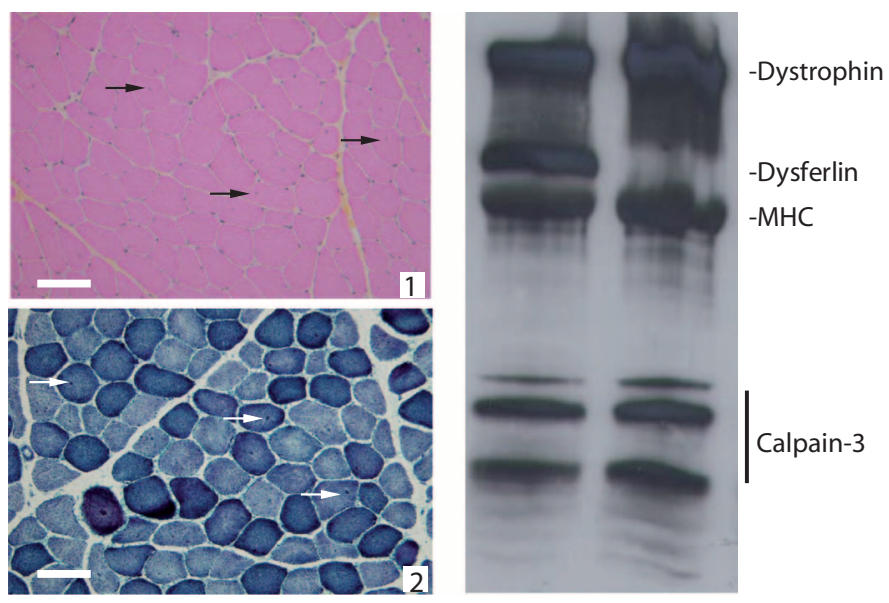

Fig. 1. Muscle histology and multiplex immunoblot. (A) Fibers are regular, and central nuclei are numerous (arrows). No necrosis, fibrosis, tubular aggregate, or inflammation was observed. 1: hematoxylin and eosin staining; 2: NADH (reduced form of nicotinamide adenine dinucleotide) dehydrogenase staining. Scale bar, $100 \mu \mathrm{m}$. (B) Multiplex immunoblot using dystrophin, myosin heavy chain (MHC), dysferlin, and calpain-3 antibodies. Lane 1: protein extracted from a nonafflicted patient muscle; lane 2: protein extracted from patient F1-26-1-2 muscle. Only the band corresponding to dysferlin is absent in patient F1-26-1-2. in exon 41 (fig. S1B). This junction fragment was sequenced and then "walked" with internal primers until the identification of the genomic junction resulting from the deletion (c.89-643_4474-2493del; Fig. 2B). Analysis of the surrounding sequences did not identify any repeated sequences explaining the deletion event at the molecular level. Fluorescence in situ hybridization (FISH) demonstrated an isolated deletion, without any additional chromosomal rearrangement (Fig. 2C and fig. S1C). Transcriptional analyses from the patient's monocytes indicated that the corresponding deleted (r.89_4410del) messenger RNA (mRNA) is expressed (Fig. 2D). Translation from the native dysferlin initiation codon would result in a reading frameshift encoding a predicted truncated protein of 58 amino acids (p.Gly30_Gln1470delfsX29; including 28 amino acids encoded from DYSF exon 41 but with a +3 reading frame). From our experience, we considered that such a truncated protein, obtained from the native initiation codon, would not explain the relatively mild and late-onset phenotype. Bioinformatic analyses of putative open reading frames (ORFs) within the deleted transcript identified a possible cryptic translation initiation codon, localized 22 bp downstream of the native translation initiation codon (Fig. 2E), which, if used in vivo, would lead to an in-frame rescue and use of the natural stop codon. Translation of the resulting transcript of 1899 nucleotides would produce a truncated minidysferlin protein of 632 residues and $73 \mathrm{kD}$ (as predicted by ExPASy $\pi$ analysis). The use of the cryptic translation initiation codon would modify the first 21 residues but maintain the wild-type C-terminal part of dysferlin (wild-type residues 1471 to 2080), including the two last C2 and the TM domains (Fig. 2F, with PSORT II and Pfam bioinformatic analysis). Immunoblot experiments with a dysferlin antibody on proteins extracted from the patient's muscle identified a $\sim 73-\mathrm{kD}$ band, supporting the use of the cryptic downstream initiation codon and the expression of a corresponding minidysferlin protein (Fig. 3A).

Localization of the minidysferlin to the muscle membrane Fluorescence-activated cell sorting (FACS) and immunofluorescence experiments, using the patient's monocytes, revealed the presence of dysferlin-positive monocytes and peripheral labeling, suggesting the proper targeting of the minidysferlin to the plasma membrane (fig. S2, A and B).

We used ectopic expression experiments in wild-type fibroblasts (Fig. 3B) to determine the stability and localization of the minidysferlin. As expected, transfection of a plasmid encoding a green fluorescent protein (GFP) full-length DYSF fusion transcript (p.GFP-DYSF) resulted in plasma membrane staining (Fig. $3 \mathrm{~B}$ ). We replaced the full-length $D Y S F$ sequence with the patient's deleted cDNA in p.GFP-DYSF (p.GFPnatATG-DYSFdel). When translated from the native translation initiation codon, the produced GFP-fused peptide only led to patchy cytoplasmic staining. Conversely, initiation of translation from the predicted cryptic translation initiation codon, with another plasmid, deleted of the 22 initial nucleotides (p.GFP-cryptATG-MiniDYSF), resulted in membrane targeting of the minidysferlin (Fig. 3B). Together, these results confirmed the use of the cryptic initiation codon and localization of the corresponding protein at the membrane.

\section{Reparation of membrane after minidysferlin gene transfer in dysferlin-deficient mice}

To further evaluate the functionality of this minidysferlin, we constructed rAAV vectors containing the ORF expressed from the cryptic initiation codon and placed under the control of the C5.12 promoter (26). 
Intramuscular injection of MiniDYSF-rAAV in the tibialis anterior (TA) and foot flexor digitorum brevis (FDB) of 1.5- or 3-month-old $\mathrm{C} 57 \mathrm{Bl} / 6$ and dysferlin-deficient female mice led to a clear and highlevel expression of the minidysferlin protein after 1 month of expression (Fig. 4, A and B), indicating the stability of the produced protein. Immunohistochemical analysis revealed that minidysferlin correctly localized to the sarcolemma (Fig. 4B). This localization corresponds to the presence of minidysferlin in intracytoplasmic membrane networks (fig. S3A). RyR colocalization experiments in sections of muscles from treated dysferlin-deficient mice demonstrated that minidysferlin localized to the T-tubule network (fig. S3B), indicating that minidysferlin expression in deficient muscles reproduces the spatiotemporal expression of dysferlin during normal development $(27,28)$. Gene transfer of minidysferlin did not cause any morphological deterioration in treated
Fig. 2. Identification of a homozygous genomic internal deletion encompassing exons 2 to 40 of DYSF in patient F1-26-1-2. (A) CGH array analysis of the DYSF locus identified a genomic internal deletion encompassing exons 2 to 40 included (left panel). The vertical axis shows the rank position of each probe along the genome, and the horizontal axis shows the $\log _{2}$ ratios (Cy3/Cy5 ratio). The patient sample was fluorescently labeled with Cy3, and a control sample (of same gender) was fluorescently labeled with Cy5. (B) Sequence analysis of the genomic breakpoint evidenced the junction between introns 1 and 40, resulting from the homozygous genomic deletion (c.89-643_4474-2493del). (C) FISH experiments on lymphocytes of the patient using two specific fluorescent probes: RP11-356 17 ( $\mathrm{H} 17$, labeled in green), selected to overlap the expected $3^{\prime}$ breakpoint, and WI2-1887A12 (A12, labeled in red), selected within the deleted region. $\mathrm{H} 17$ hybridized to chromosome 2 of the patient and a control on both chromosomes (arrows). A12 only hybridized on both chromosomes from the control, but not from the patient (arrowheads). (D) Sequence analysis of the DYSF transcript performed on CDNA obtained from the patient's monocytes, revealing a deletion of exons 2 to 40 (r.89_4410del). (E) Bioinformatic analysis using ORF Finder for putative ORF within the r.89_4410del CDNA. Top: putative ORF predicted using the native start codon (in red) and terminating by a premature termination codon (PTC; in red) in exon 41; bottom: ORF predicted using the cryptic start codon (in green) at position 23 and terminating by natural stop codon (in green). Nucleotide positions are indicated on the r.89_4410del cDNA. (F) Scheme of the predicted minidysferlin protein according to bioinformatic analyses of protein domains, in comparison to wild-type dysferlin. Location of the NCL-Hamlet epitope (amino acids 1999 to 2016) is also depicted. NLS, nuclear localization signal.
A

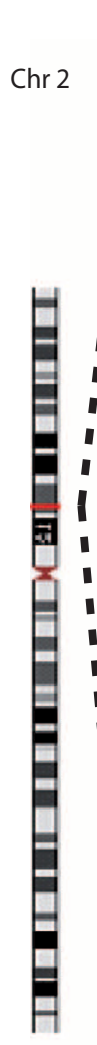

B

Breakpoint

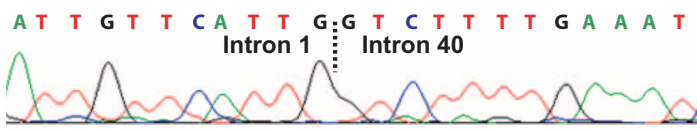

C
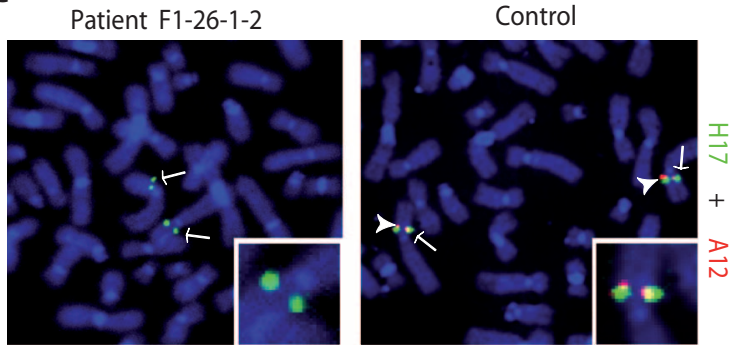

$+75871 \mathrm{bp}$

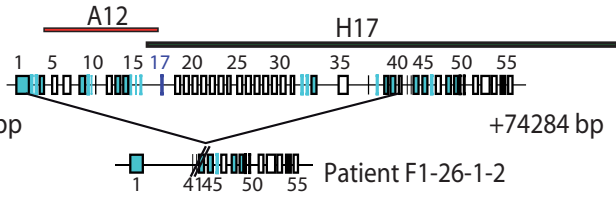

71560650

D

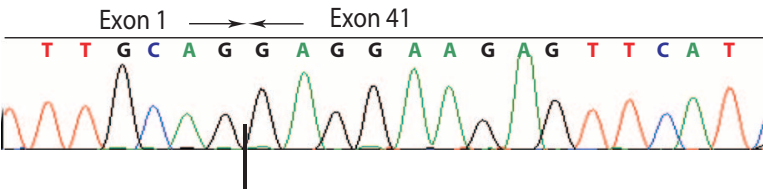

E

Putative ORF predicted using the native start codon and terminating by a PTC in exon 41
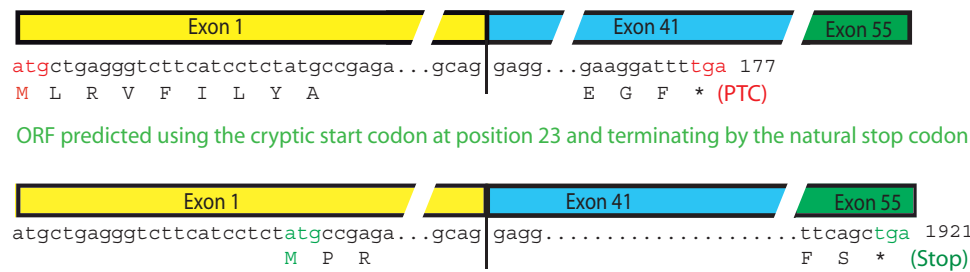

$\mathbf{F}$

\begin{tabular}{|c|c|c|c|c|c|c|c|c|}
\hline \multicolumn{3}{|c|}{${ }_{\text {Bipartite NLS }}$} & NLS & Dysferlin & 230 & & \multicolumn{2}{|c|}{$\begin{array}{l}\text { Hamlet } \\
\text { antibody }\end{array}$} \\
\hline A & B & C & & & D & $\bar{E}$ & $\mathbf{F}$ & G \\
\hline & & & & Minidysferlin & 73 & & $\mathbf{F}$ & G \\
\hline & & & & & seque & & & dom \\
\hline
\end{tabular}


A

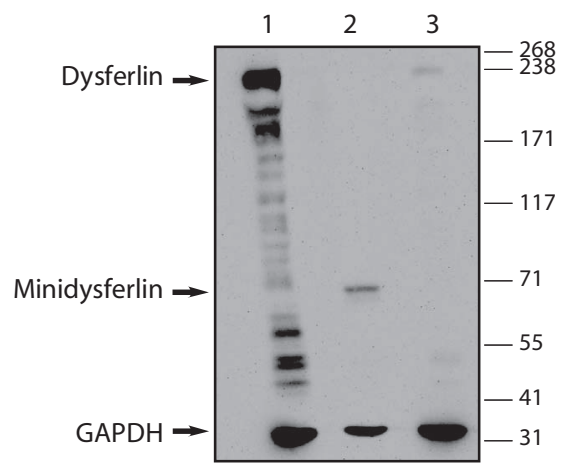

B

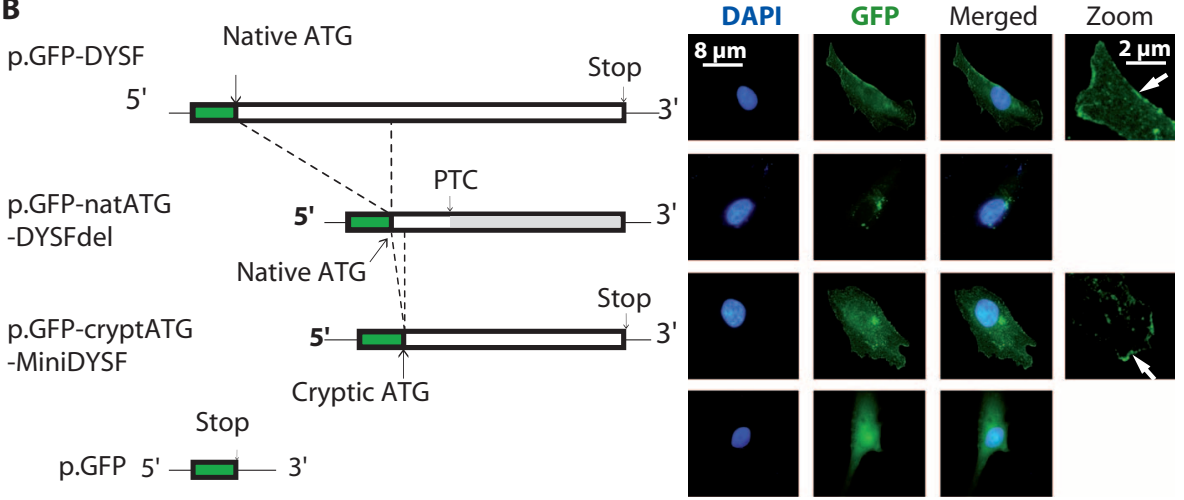

Fig. 3. Identification of a minidysferlin protein expressed by translation from a cryptic initiation codon. (A) Immunoblot experiments with dysferlin antibodies on muscle biopsies from a healthy control (lane 1), patient F1-26-1-2 (lane 2), and a patient affected with dysferlinopathy (lane 3). A single band around the predicted molecular size of $73 \mathrm{kD}$, corresponding to the minidysferlin, was detected in patient F1-26-1-2. Glyceraldehyde-3-phosphate dehydrogenase (GAPDH) labeling was used to evaluate the loading. (B) Ectopic expression experiments in wildtype fibroblasts with different GFPDYSF fusion transcripts detailed below and in Materials and Methods (p.GFP-DYSF: plasmid containing GFP

muscles as compared by hematoxylin-phloxine-saffron (HPS) staining of TA sections from treated and dysferlin-deficient muscles (Fig. 4C).

To evaluate the efficacy of minidysferlin in sarcolemmal repair, we used a membrane repair assay in FDB-isolated muscle fibers after intramuscular injection in mice. This assay is based on membrane wounding of isolated FDB fibers with a two-photon laser-scanning microscope in the presence of FM1-43 dye (7). Mice were injected with either MiniDYSF-rAAV vectors or vehicle alone. In dysferlin-deficient fibers injected with vehicle only in the presence of calcium, FM1-43 dye penetrated continuously into the damaged fiber as seen in representative images and box plots (Fig. 4, D and E). In contrast, MiniDYSF-rAAV-injected fibers were able to halt the penetration of FM1-43 dye, indicating efficient membrane repair compared to fibers from C $57 \mathrm{Bl} / 6$ mice. In some dysferlin-deficient fibers injected with MiniDYSF-rAAV, fluorescence levels were observed at intensities similar to that in fibers from dysferlindeficient noninjected muscle, probably due to the presence of nonexpressing fibers. These findings correlate with the immunohistochemical analyses, which evidenced incomplete transduction efficiencies. Nevertheless, a significant difference $(P=0.012)$ was observed when comparing muscle fibers from MiniDYSF-rAAV-injected and vehicle-injected fibers.

\section{DISCUSSION}

Our results identify a natural minidysferlin protein that retains at least partial functionality, as shown by the restoration of membrane resealing activity, the main physiological function attributed to dysferlin. These findings could be important for the development of possible therapeutic approaches for dysferlinopathies. The specific expression in skeletal muscle fibers of full-length dysferlin is sufficient to rescue the muscular dystrophy in dysferlin-deficient mice (29). Unfortunately, the coding sequence of dysferlin is too large for single rAAV vector gene transfer. Concatemerization of rAAV vectors has been shown to be an alternative but is limited by a decrease of efficiency as compared
cDNA fused to full-length DYSF cDNA; p.GFP-natATG-DYSFdel: plasmid containing GFP CDNA fused to the entire r.89_4410del CDNA identified in the patient, resulting in a PTC and precluding translation until the $C$ terminus of dysferlin; p.GFP-cryptATG-MiniDYSF: plasmid containing GFP cDNA fused to the r.89_4410del cDNA, deleted from its 22 initial nucleotides, allowing for in-frame translation from the cryptic translation initiation codon to the C terminus of dysferlin; p.GFP: control GFP plasmid). Only p.GFP-DYSF and p.GFP-cryptATG-MiniDYSF constructs allowed the localization of the protein at the periphery of the cells (white arrows). Scale bar, 8 $\mu \mathrm{m}$; zoom scale bar, $2 \mu \mathrm{m}$.

to single rAAV gene transfer (21). The size of the minidysferlin cDNA identified in this study is within the optimal packaging size of rAAV vectors. In addition, our findings demonstrate the modularity of the dysferlin protein, an essential prerequisite for minigene and exonskipping approaches. The identification of this partially functional minidysferlin was based on a clinical observation and subsequent functional evaluations, whereas previous studies on possible modularity of dysferlin used empiric constructions based on structural information of the dysferlin protein $(28,30)$.

Notably, the minidysferlin identified in this report contains the last two C-terminal C2 domains, a functional structure for vesicle trafficking and membrane exocytosis observed in synaptotagmin VII, a protein implicated in membrane fusion events, leading to neurotransmitter release (31). In dysferlin, these $\mathrm{C} 2$ domains together with the TM domain constitute a possible minimal configuration for functionality regarding the role of the protein in sarcolemma repair. Besides, the importance of this C-terminal region is supported by the existence of severe phenotypes associated with mutations in this region $(16,18)$. At the histological level in mouse muscles, the almost absent correction of the dystrophic pattern could be explained by the fact that fixing the membrane repair capacity is not sufficient to restore the entire functionality of dysferlin. Additional C2 domains, absent in this minidysferlin, might confer specific functional roles and be necessary for full dysferlin functionality. This could explain why, although moderate, a phenotype is still observed associated with the reported natural minidysferlin in the patient. The mild histologic pattern observed, as compared to those associated to other mutations in DYSF, suggests a slowing down of the dystrophic process.

Both miniprotein and exon-skipping approaches have previously been evaluated at the preclinical level as possible therapeutic approaches for Duchenne muscular dystrophy (DMD). A natural proof of concept for functional redundancy of specific domains of the dystrophin protein was demonstrated in patients affected with the milder allelic disease, Becker muscular dystrophy. In these patients, in-frame 
A

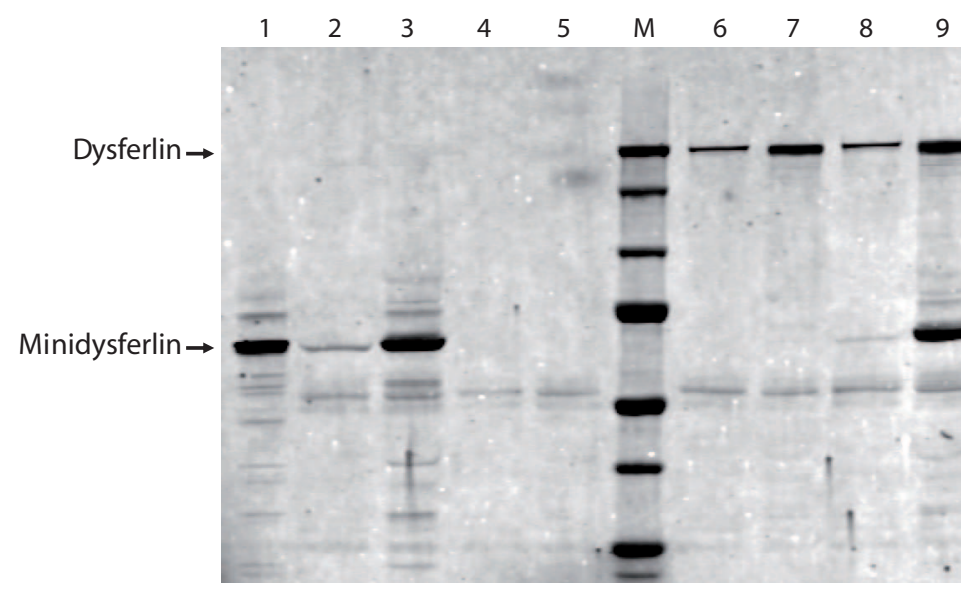

C
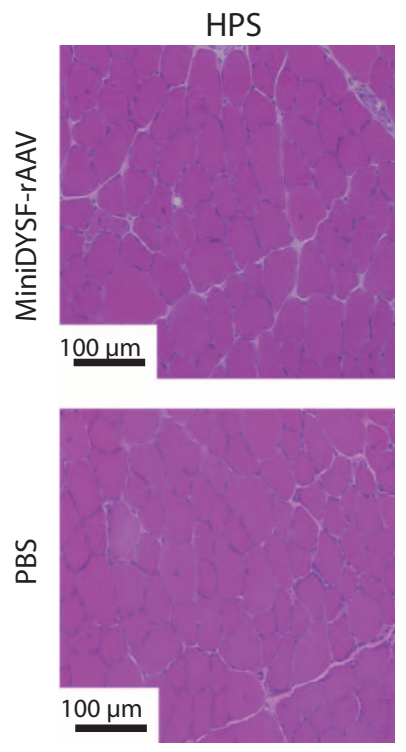

D
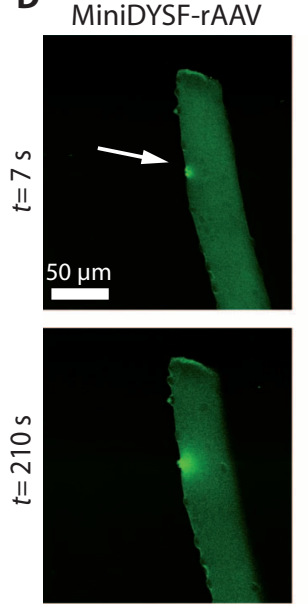

B
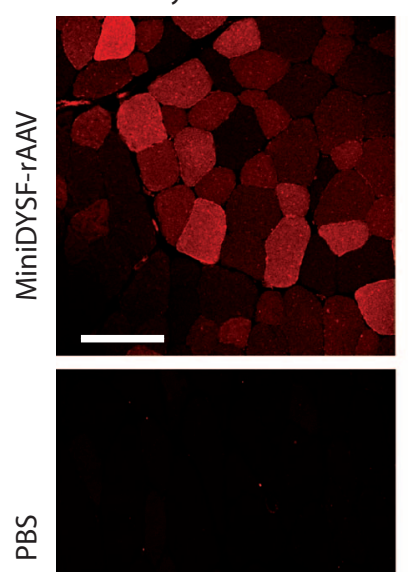

ณ
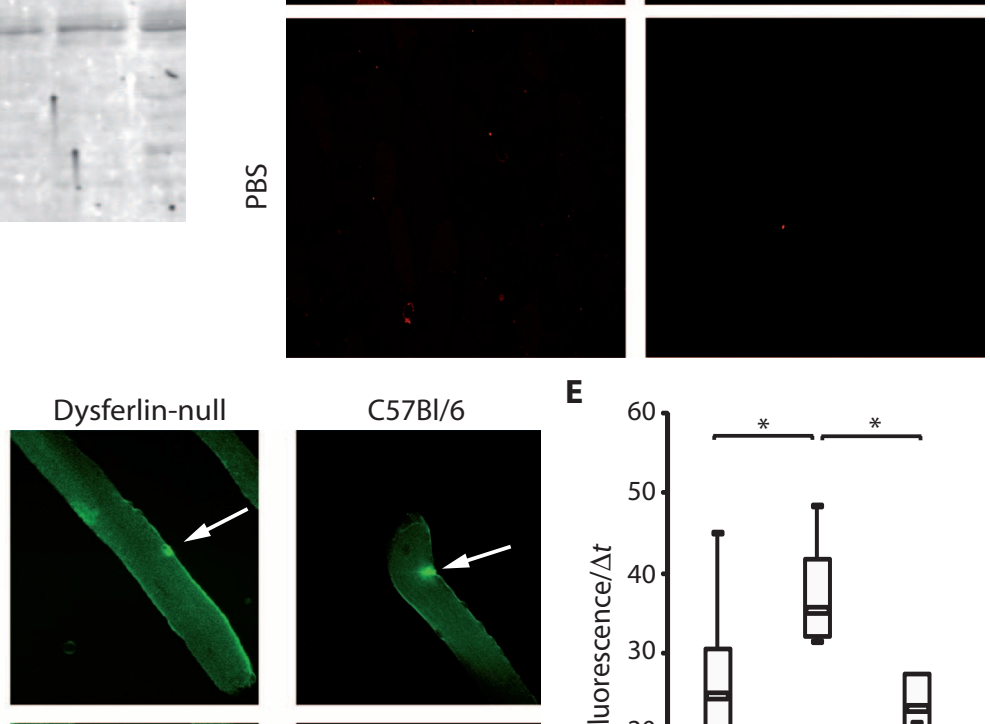

E
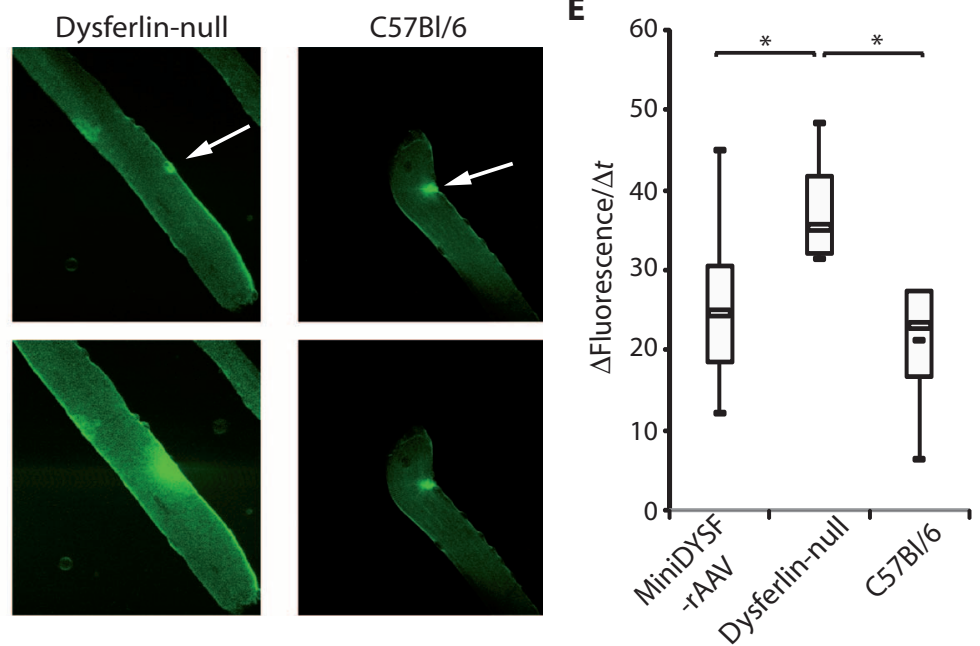

Fig. 4. Characterization of minidysferlin using protein, histological, and functional evaluation of muscles from injected mice. (A) Immunoblot detection of dysferlin in FDB (lanes 2, 4, 6, and 8) and TA (lanes 3, 5, 7, and 9) muscles. Lanes 2 to 5: dysferlin-deficient mice; lanes 6 to 9: wild-type mice. Treated (lanes 2, 3, 8, and 9) or not (lanes 4 to 7) with rAAV vectors encoding minidysferlin. The dysferlin antibody recognizes both the murine and the human proteins. Lane 1 corresponds to a positive control: proteins extracted from fibroblasts expressing a minidysferlin construct. $\mathrm{M}$ indicates the Precision Plus Protein Standards (Bio-Rad; size of the visible bands from top to bottom in kD: 250, 150, 100, 75, 50, 37, and 25). A band corresponding to the minidysferlin was observed in all treated muscles. Full-length dysferlin was detected only in the wild-type animals. (B) Immunofluorescence experiments (transversal sections) with dysferlin antibodies in dysferlin-deficient mice muscles treated (MiniDYSF-rAAV) or untreated (PBS) with rAAV vectors encoding minidysferlin. In injected muscles, clear labeling of the sarcolemma and the intracellular compartment was observed with dysferlin antibodies. No signal was detected in PBS-injected muscles or when the primary antibodies were omitted (Control). Scale bar, $50 \mu \mathrm{m}$. (C) Histological analyses of muscles. Frozen sections of TA muscles stained with HPS. Upper panel: muscle from dysferlindeficient mouse muscles injected with rAAV; lower panel: dysferlindeficient muscle. No clear difference was observed between injected and noninjected dysferlin-deficient muscle, suggesting that minidysferlin expression did not cause additional deleterious histological changes. Scale bars are indicated on images. (D) Functional evaluation of minidysferlin using a membrane repair assay on isolated muscle fibers from injected mice. Fibers were isolated from MiniDYSF-rAAV-injected and noninjected dysferlin-deficient and wild-type mice and analyzed by laser-wounding assay in the presence of the FM1-43 dye. Images are represented in 8-bit green false color from the ImageJ software (http://rsb.info.nih.gov/ij/). Images represent the fibers $7 \mathrm{~s}$ (upper panels) and $210 \mathrm{~s}$ (lower panels) after the lesion. The two left panels show a representative assay performed on dysferlin-deficient mice injected with rAAV vectors encoding the minidysferlin in the presence of $\mathrm{Ca}^{2+}$. The two central panels show a representative repair assay performed on dysferlin-deficient fibers in the presence of $\mathrm{Ca}^{2+}$. Finally, the two right panels show a representative assay performed on wild-type mice. Sites of lesion are indicated by arrows. Scale bar, $50 \mu \mathrm{m}$. (E) Box plots represent the deduced speed of fluorescence influx ( $\Delta$ [fluorescence] $/ \Delta t$ ) in the fibers of dysferlin-deficient muscles injected with MiniDYSF-rAAV $(n=16)$, dysferlin-deficient $(n=6)$, and C57BI/6 $(n=5)$. Boxes embrace the 25 th and 75 th percentile values. Whiskers extend from each end of the box to the minimum and maximum values; the horizontal bold bars indicate the median value. ${ }^{*} P<0.001$, compared to noninjected dysferlin-deficient mice. 
internal deletions of the dystrophin gene lead to the expression of truncated dystrophins maintaining partial functionality (32). Notably, exon-skipping strategies recently led to promising results in clinical trials in DMD patients (33). In a recent report based on a natural proof of principle that a deletion of dysferlin exon 32 leads to a mild and late phenotype (34), we demonstrated the pertinence and feasibility of antisense-induced exon skipping to bypass mutations in dysferlin exon 32 (35). The identification of a partially functional minidysferlin in the present report and, as a consequence, the modularity of the dysferlin protein further outline dysferlinopathies as the second group of muscular dystrophies to be possibly targeted by exon-skipping strategies.

\section{MATERIALS AND METHODS}

\section{Patient and healthy control materials}

Informed consent was obtained from all individuals included in this study. Genomic DNA, protein extracts, and lymphoblastoid cell lines were obtained with standard protocols. $\mathrm{CD} 14^{+} \mathrm{CD} 16^{+}$monocytes were obtained from peripheral blood mononuclear cells isolated from whole blood with the EasySep Human Monocyte Enrichment kit (Stem Cell) according to the manufacturer's recommendations. mRNA was obtained from total peripheral blood mononuclear cells with the Nucleospin RNA II kit (Clontech).

\section{Genomic and transcriptional mutation analyses}

Genomic PCR amplification of DYSF exons and flanking intronic boundaries was performed as previously described (16). CGH array analysis was performed as described (36) on four-plex custom oligonucleotide arrays specifically designed to cover the genomic DYSF locus. Arrays were scanned at a $2-\mu \mathrm{m}$ resolution with a NimbleGen MS 200 Microarray Scanner. Fluorescence intensity raw data were obtained from scanned images of the oligonucleotide tiling arrays with NimbleScan 2.0 extraction software (Roche NimbleGen Inc.) and interpreted with SignalMap software (Roche NimbleGen Inc.). Long-range PCR was used for the determination of the genomic deletion breakpoint as previously described (18) with primer pairs 5'-GTCTTTTGCTCCCTCTCACG-3' (forward) and 5'-GCTCCACCAATCGATGAACT-3' (reverse). The obtained junction fragment was sequenced by "walking" with internal primers to identify the genomic junction sequence resulting from the deletion. One particular forward primer (5'-CAGGCACTTGCCCCTTCATGC-3') in intron 1 revealed the genomic junction. The RNA obtained from the patient's monocytes was reverse transcription PCR-amplified with specifically designed primers (forward, 5'-TCTAAGCCAGGAGCCAGAGA-3'; reverse, 5'-GATGTAAGGATCACACTTTCCA-3'; amplification conditions available upon request), sequenced on an ABI3130xl Genetic Analyzer (Applied Biosystems), and analyzed with Sequencher software (Gene Codes Corporation). Mutational data are described with the nomenclature of the Human Genome Variation Society (http:// www.hgvs.org/mutnomen). Nucleotide numbering reflects cDNA numbering, with +1 corresponding to the A of the ATG translation initiation codon in the reference sequence (human DYSF, GenBank NM_003494.2). The native initiation codon is codon 1 .

\section{Fluorescence in situ hybridization}

FISH experiments were performed on lymphoblastoid cell lines from the patient and control subjects as previously described (37) with bacterial artificial chromosome (RP11-356H17, RP11-161M21) and fosmid
(WI2-1887A12) clones obtained from the Sanger Institute (http://www. sanger.ac.uk), specifically selected in the region of the DYSF locus.

\section{Immunoblot}

Detection of dysferlin was performed with standard protocols with primary antibodies to dysferlin (NCL-Hamlet, Novocastra) diluted 1:300 on human muscle protein extracts, and diluted 1:500 on protein extracts from murine muscles.

\section{Histology and immunohistochemistry}

Cryosections (8- or 10- $\mu \mathrm{m}$ thickness) were prepared from frozen muscles. Histological staining was performed with hematoxylin-phloxinesaffron (HPS). Histological alterations in dysferlin-deficient mice before gene transfer have been extensively quantified (21). Immunodetection was performed with the monoclonal antibody dysferlin-Hamlet (NCL-Hamlet, diluted 1:20), and sections were examined under a Leica confocal microscope. Sections were mounted with Fluoromount-G (Southern Biotech).

\section{Ectopic expression experiments}

p.GFP-DYSF (30) was a gift from K. Bushby (Institute of Human Genetics, Newcastle, UK). To generate p.GFP-natATG-DYSFdel, we used a fusion PCR protocol. Two PCR fragments were amplified from p.GFP-DYSF, respectively, with primer pairs 5'-GACCTCCATAGAAGACACCG-3' (forward) $/ 5^{\prime}$-ACCAGGACGTCCACAGGATG-3' (reverse) and 5' CCAGGAGCCAGAGATTCG-3' (forward)/5'-AAATGATGGAAGTGGGGTGA-3' (reverse). These two PCR fragments were then fused by PCR amplification with the forward primer $5^{\prime}$-GACCTCCATAGAAGACACCG-3' and the reverse primer 5'-AAATGATGGAAGTGGGGTGA-3'. The obtained fragment was inserted into the Eco RI-Cla I sites of p.GFPDYSF. We next generated p.GFP-cryptATG-MiniDYSF by amplifying a PCR fragment from p.GFP-natATG-DYSFdel with the forward primer 5'-AAAAGAATTCATGCCGAGAACGTCCACACACCCG-3' and the reverse primer $5^{\prime}$-AAATGATGGAAGTGGGGTGA-3'. The obtained fragment was inserted into the Eco RI-Cla I sites of p.GFP-natATG-DYSFdel. Constructs were sequenced on an ABI3130xl Genetic Analyzer and analyzed with Sequencher software. According to the manufacturer's instructions, nucleofection was performed with program P-22 and NHDF kits (Amaxa) on human primary fibroblasts (AG16409; Coriell Cell Repository). These cells were fixed with $4 \%$ paraformaldehyde for $10 \mathrm{~min}$. DNA labeling was performed with 4',6-diamidino-2-phenylindole (50 ng/ml). Slides were observed on a DMR microscope (Leica), and pictures were taken with a CoolSnap camera (Roper Scientific).

\section{Bioinformatic analysis}

PSORT II was used to predict protein subcellular localization (http:// www.psort.org/). Prediction of the molecular weight, ORF, and protein sequence comparison were performed with http://expasy.org/ tools/pi_tool.html, http://www.ncbi.nlm.nih.gov/projects/gorf/, and http://expasy.org/tools/blast/, respectively.

\section{rAAV production}

Adenovirus-free rAAV2/1 and rAAV2/9 viral preparations were generated as described $(38,39)$. Crude viral lysate was harvested at 60 hours after transfection. To facilitate viral particle release, we sequentially treated crude lysate with four rounds of freeze-thaw, digestion with benzonase $\left(15 \mathrm{~s}\right.$ at $\left.37^{\circ} \mathrm{C}\right)$, and ammonium sulfate precipitation. Finally, the viral lysate was purified through two rounds of $\mathrm{CsCl}$ ultracentrifugation followed 
by dialysis to eliminate $\mathrm{CsCl}$. After DNA extraction by successive treatments with deoxyribonuclease I and proteinase $\mathrm{K}$, viral genomes were quantified by a TaqMan real-time PCR assay with primers and probes corresponding to the inverted terminal repeat (ITR) region of the AAV vector genome (40). The primer pairs and TaqMan probes used for ITR amplification were as follows: 1AAV65/Fwd, 5'-CTCCATCACTAGGGGTTCCTTGTA-3'; 64AAV65/rev, 5'-TGGCTACGTAGATAAGTAGCATGGC-3'; and AAV65MGB/taq, 5'-GTTAATGATTAACCC-3'. Titration of MiniDYSF-rAAV vectors is expressed as viral genome per milliliter $(\mathrm{vg} / \mathrm{ml})$.

\section{In vivo experiments}

$\mathrm{C} 57 \mathrm{Bl} / 6$ and $\mathrm{A} / \mathrm{J}$ mice were purchased from Charles River Laboratories. $\mathrm{A} / \mathrm{J}$ mice backcrossed onto C57Bl/6 background through N4 were used in this study. Previous experiments by Lostal and colleagues indicated that such a background did not change the overall muscle presentation (21). All mice were handled according to the European guidelines for use of experimental animals. Mice were injected into the right TA muscle with $30 \mu \mathrm{l}$ of phosphate-buffered saline (PBS) and into the left TA with $30 \mu \mathrm{l}$ of MiniDYSF-rAAV $\left(1.5 \times 10^{12} \mathrm{vg} / \mathrm{kg}\right)$ and with $15 \mu \mathrm{l}$ in FDB $\left(0.75 \times 10^{12} \mathrm{vg} / \mathrm{kg}\right)$ for membrane repair monitoring. One month after the injection, mice were sacrificed and muscles were removed and quickly frozen in liquid nitrogen-cooled isopentane.

\section{Membrane injury and membrane repair monitoring}

The assay was performed on isolated single fibers from the FDB muscles of 3- to 4-month-old dysferlin-deficient mice injected $(n=4)$ or not $(n=3)$ and $\mathrm{C} 57 \mathrm{Bl} / 6$ mice $(n=3)$ in the presence or absence of calcium and in the presence of FM1-43 dye (final concentration, $4 \mu \mathrm{M}$; Invitrogen). To induce damage, we irradiated an area at the sarcolemma $\left(\sim 5 \mu \mathrm{m}^{2}\right)$ of the muscle fiber at full power for $1 \mathrm{~s}$ with a two-photon confocal laser-scanning microscope. The multiphoton microscope consisted of a Radiance $2100 \mathrm{MP}$ scan head (Bio-Rad) equipped with a mode-locked titanium-sapphire laser system (Coherent VerdiMira, Science and Technology Facilities Council) pumped at $10 \mathrm{~W}$ and tuned to an 800 -nm excitation with 100 -fs pulses at $76 \mathrm{MHz}$. The microscope was an inverted Nikon TE300 (Nikon Instruments Inc.) with Nikon objectives (dry CFI Plan APO, 20 Å; numerical aperture, 0.75). Images were captured for 3 min after the irradiation at 7-s intervals. For every image taken, the fluorescence intensity at the site of the damage was measured by ImageJ on an area of $\sim 0.01 \mathrm{~mm}^{2}$. The rate of fluorescence influx for each group was represented as box plots.

\section{Statistical analysis}

Comparisons of means were performed with the Student-NewmanKeuls post hoc test after significant analysis of variance (ANOVA).

\section{REFERENCES AND NOTES}

1. R. Bashir, S. Britton, T. Strachan, S. Keers, E. Vafiadaki, M. Lako, I. Richard, S. Marchand, N. Bourg, Z. Argov, M. Sadeh, I. Mahjneh, G. Marconi, M. R. Passos-Bueno, S. Moreira Ede, M. Zatz, J. S.
Beckmann, K. Bushby, A gene related to Caenorhabditis elegans spermatogenesis factor fer-1 is mutated in limb-girdle muscular dystrophy type 2B. Nat. Genet. 20, 37-42 (1998).

2. J. Liu, M. Aoki, I. Illa, C. Wu, M. Fardeau, C. Angelini, C. Serrano, J. A. Urtizberea, F. Hentati, M. B. Hamida, S. Bohlega, E. J. Culper, A. A. Amato, K. Bossie, J. Oeltjen, K. Bejaoui, D. McKennaYasek, B. A. Hosler, E. Schurr, K. Arahata, P. J. de Jong, R. H. Brown Jr., Dysferlin, a novel skeletal muscle gene, is mutated in Miyoshi myopathy and limb girdle muscular dystrophy. Nat. Genet. 20, 31-36 (1998).

3. M. Aoki, K. Arahata, R. H. Brown Jr., Positional cloning of the gene for Miyoshi myopathy and limb-girdle muscular dystrophy. Rinsho Shinkeigaku 39, 1272-1275 (1999).

4. K. M. Bushby, Dysferlin and muscular dystrophy. Acta Neurol. Belg. 100, 142-145 (2000).

5. K. Nguyen, G. Bassez, M. Krahn, R. Bernard, P. Laforêt, V. Labelle, J. A. Urtizberea, D. FigarellaBranger, N. Romero, S. Attarian, F. Leturcq, J. Pouget, N. Lévy, B. Eymard, Phenotypic study in 40 patients with dysferlin gene mutations: High frequency of atypical phenotypes. Arch. Neurol. 64, 1176-1182 (2007).

6. J. Meldolesi, Surface wound healing: A new, general function of eukaryotic cells. J. Cell. Mol. Med. 7, 197-203 (2003).

7. D. Bansal, K. Miyake, S. S. Vogel, S. Groh, C. C. Chen, R. Williamson, P. L. McNeil, K. P. Campbell, Defective membrane repair in dysferlin-deficient muscular dystrophy. Nature 423, 168-172 (2003).

8. L. V. Anderson, K. Davison, J. A. Moss, C. Young, M. J. Cullen, J. Walsh, M. A. Johnson, R. Bashir, S. Britton, S. Keers, Z. Argov, I. Mahjneh, F. Fougerousse, J. S. Beckmann, K. M. Bushby, Dysferlin is a plasma membrane protein and is expressed early in human development. Hum. Mol. Genet. 8, 855-861 (1999).

9. D. B. Davis, K. R. Doherty, A. J. Delmonte, E. M. McNally, Calcium-sensitive phospholipid binding properties of normal and mutant ferlin C2 domains. J. Biol. Chem. 277, 22883-22888 (2002).

10. N. De Luna, A. Freixas, P. Gallano, L. Caselles, R. Rojas-García, C. Paradas, G. Nogales, R. Dominguez-Perles, L. Gonzalez-Quereda, J. J. Vilchez, C. Márquez, J. Bautista, A. Guerrero, J. A. Salazar, A. Pou, I. Illa, E. Gallardo, Dysferlin expression in monocytes: A source of mRNA for mutation analysis. Neuromuscul. Disord. 17, 69-76 (2007).

11. N. Wein, M. Krahn, S. Courrier, M. Bartoli, E. Salort-Campana, K. Nguyen, C. Fernandez, J. Pouget, C. Fossat, D. Depetris, F. Leturcq, P. Cau, N. Levy, Immunolabelling and flow cytometry as new tools to explore dysferlinopathies. Neuromuscul. Disord. 20, 57-60 (2010).

12. E. A. Nalefski, J. J. Falke, The C2 domain calcium-binding motif: Structural and functional diversity. Protein Sci. 5, 2375-2390 (1996).

13. C. Therrien, D. Dodig, G. Karpati, M. Sinnreich, Mutation impact on dysferlin inferred from database analysis and computer-based structural predictions. J. Neurol. Sci. 250, 71-78 (2006).

14. M. Aoki, J. Liu, I. Richard, R. Bashir, S. Britton, S. M. Keers, J. Oeltjen, H. E. Brown, S. Marchand, N. Bourg, C. Beley, D. McKenna-Yasek, K. Arahata, S. Bohlega, E. Cupler, I. Illa, I. Majneh, R. J. Barohn, J. A. Urtizberea, M. Fardeau, A. Amato, C. Angelini, K. Bushby, J. S. Beckmann, R. H. Brown Jr., Genomic organization of the dysferlin gene and novel mutations in Miyoshi myopathy. Neurology 57, 271-278 (2001).

15. R. Cagliani, F. Fortunato, R. Giorda, C. Rodolico, M. C. Bonaglia, M. Sironi, M. G. D’Angelo, A. Prelle, F. Locatelli, A. Toscano, N. Bresolin, G. P. Comi, Molecular analysis of LGMD-2B and MM patients: Identification of novel DYSF mutations and possible founder effect in the Italian population. Neuromuscul. Disord. 13, 788-795 (2003).

16. K. Nguyen, G. Bassez, R. Bernard, M. Krahn, V. Labelle, D. Figarella- Branger, J. Pouget, H. Hammouda el, C. Béroud, A. Urtizberea, B. Eymard, F. Leturcq, N. Lévy, Dysferlin mutations in LGMD2B, Miyoshi myopathy, and atypical dysferlinopathies. Hum. Mutat. 26, 165 (2005).

17. M. Guglieri, K. Bushby, How to go about diagnosing and managing the limb-girdle muscular dystrophies. Neurol. India 56, 271-280 (2008).

18. M. Krahn, C. Béroud, V. Labelle, K. Nguyen, R. Bernard, G. Bassez, D. Figarella-Branger, C. Fernandez, J. Bouvenot, I. Richard, E. Ollagnon-Roman, J. A. Bevilacqua, E. Salvo, S. Attarian, F. Chapon, J. F. Pellissier, J. Pouget, H. Hammouda el, P. Laforêt, J. A. Urtizberea, B. Eymard, F. Leturcq, N. Lévy, Analysis of the DYSF mutational spectrum in a large cohort of patients. Hum. Mutat. 30, E345-E375 (2009).

19. M. Krahn, A. Borges, C. Navarro, R. Schuit, T. Stojkovic, Y. Torrente, N. Wein, C. Pécheux, N. Lévy, Identification of different genomic deletions and one duplication in the dysferlin gene using multiplex ligation-dependent probe amplification and genomic quantitative PCR. Genet. Test. Mol. Biomarkers 13, 439-442 (2009).

20. J. C. Grieger, R. J. Samulski, Packaging capacity of adeno-associated virus serotypes: Impact of larger genomes on infectivity and postentry steps. J. Virol. 79, 9933-9944 (2005).

21. W. Lostal, M. Bartoli, N. Bourg, C. Roudaut, A. Bentaïb, K. Miyake, N. Guerchet, F. Fougerousse, P. McNeil, I. Richard, Efficient recovery of dysferlin deficiency by dual adeno-associated vectormediated gene transfer. Hum. Mol. Genet. 19, 1897-1907 (2010).

22. B. Wang, J. Li, X. Xiao, Adeno-associated virus vector carrying human minidystrophin genes effectively ameliorates muscular dystrophy in $m d x$ mouse model. Proc. Natl. Acad. Sci. U.S.A. 97, 13714-13719 (2000).

23. P. Gregorevic, J. M. Allen, E. Minami, M. J. Blankinship, M. Haraguchi, L. Meuse, E. Finn, M. E. Adams, S. C. Froehner, C. E. Murry, J. S. Chamberlain, rAAV6-microdystrophin preserves muscle function and extends lifespan in severely dystrophic mice. Nat. Med. 12, 787-789 (2006). 
24. A. Goyenvalle, A. Vulin, F. Fougerousse, F. Leturcq, J. C. Kaplan, L. Garcia, O. Danos, Rescue of dystrophic muscle through U7 snRNA-mediated exon skipping. Science 306, 1796-1799 (2004).

25. T. Ragot, N. Vincent, P. Chafey, E. Vigne, H. Gilgenkrantz, D. Couton, J. Cartaud, P. Briand, J. C. Kaplan, M. Perricaudet, A. Kahn, Efficient adenovirus-mediated transfer of a human minidystrophin gene to skeletal muscle of $m d x$ mice. Nature 361, 647-650 (1993).

26. X. Li, E. M. Eastman, R. J. Schwartz, R. Draghia-Akli, Synthetic muscle promoters: Activ ities exceeding naturally occurring regulatory sequences. Nat. Biotechnol. 17, 241-245 (1999).

27. L. Klinge, J. Harris, C. Sewry, R. Charlton, L. Anderson, S. Laval, Y. H. Chiu, M. Hornsey, V. Straub, R. Barresi, H. Lochmüller, K. Bushby, Dysferlin associates with the developing T-tubule system in rodent and human skeletal muscle. Muscle Nerve 41, 166-173 (2010).

28. L. Klinge, S. Laval, S. Keers, F. Haldane, V. Straub, R. Barresi, K. Bushby, From T-tubule to sarcolemma: Damage-induced dysferlin translocation in early myogenesis. FASEB J. 21, 1768-1776 (2007).

29. D. P. Millay, M. Maillet, J. A. Roche, M. A. Sargent, E. M. McNally, R. J. Bloch, J. D. Molkentin, Genetic manipulation of dysferlin expression in skeletal muscle: Novel insights into muscular dystrophy. Am. J. Pathol. 175, 1817-1823 (2009).

30. D. J. Hernández-Deviez, S. Martin, S. H. Laval, H. P. Lo, S. T. Cooper, K. N. North, K. Bushby, R. G. Parton, Aberrant dysferlin trafficking in cells lacking caveolin or expressing dystrophy mutants of caveolin-3. Hum. Mol. Genet. 15, 129-142 (2006).

31. A. Reddy, E. V. Caler, N. W. Andrews, Plasma membrane repair is mediated by $\mathrm{Ca}^{2+}$-regulated exocytosis of lysosomes. Cell 106, 157-169 (2001).

32. C. Béroud, S. Tuffery-Giraud, M. Matsuo, D. Hamroun, V. Humbertclaude, N. Monnier, M. P. Moizard, M. A. Voelckel, L. M. Calemard, P. Boisseau, M. Blayau, C. Philippe, M. Cossée, M. Pagès, F. Rivier, O. Danos, L. Garcia, M. Claustres, Multiexon skipping leading to an artificial DMD protein lacking amino acids from exons 45 through 55 could rescue up to $63 \%$ of patients with Duchenne muscular dystrophy. Hum. Mutat. 28, 196-202 (2007).

33. A. Aartsma-Rus, I. Fokkema, J. Verschuuren, I. Ginjaar, J. van Deutekom, G. J. van Ommen, J. T. den Dunnen, Theoretic applicability of antisense-mediated exon skipping for Duchenne muscular dystrophy mutations. Hum. Mutat. 30, 293-299 (2009).

34. M. Sinnreich, C. Therrien, G. Karpati, Lariat branch point mutation in the dysferlin gene with mild limb-girdle muscular dystrophy. Neurology 66, 1114-1116 (2006).

35. N. Wein, A. Avril, M. Bartoli, C. Beley, S. Chaouch, P. Laforêt, A. Behin, G. Butler-Browne, V. Mouly, M. Krahn, L. Garcia, N. Lévy, Efficient bypass of mutations in dysferlin deficient patient cells by antisense-induced exon skipping. Hum. Mutat. 31, 136-142 (2010).

36. Y. Saillour, M. Cossée, F. Leturcq, A. Vasson, C. Beugnet, K. Poirier, V. Commere, S. Sublemontier, M. Viel, F. Letourneur, J. C. Barbot, N. Deburgrave, J. Chelly, T. Bienvenu, Detection of exonic copy-number changes using a highly efficient oligonucleotide-based comparative genomic hybridization-array method. Hum. Mutat. 29, 1083-1090 (2008).
37. V. Delague, M. Souaid, E. Chouery, D. Depetris, D. Sanlaville, M. G. Mattei, A. Mégarbané, Screening for subtelomeric rearrangements using automated fluorescent genotyping of microsatellite markers: A Lebanese study. Eur. J. Med. Genet. 49, 117-126 (2006).

38. M. Bartoli, C. Roudaut, S. Martin, F. Fougerousse, L. Suel, J. Poupiot, E. Gicquel, F. Noulet, O. Danos, I. Richard, Safety and efficacy of AAV-mediated calpain 3 gene transfer in a mouse model of limb-girdle muscular dystrophy type 2A. Mol. Ther. 13, 250-259 (2006).

39. S. Duque, B. Joussemet, C. Riviere, T. Marais, L. Dubreil, A. M. Douar, J. Fyfe, P. Moullier, M. A Colle, M. Barkats, Intravenous administration of self-complementary AAV9 enables transgene delivery to adult motor neurons. Mol. Ther. 17, 1187-1196 (2009).

40. U. P. Rohr, M. A. Wulf, S. Stahn, U. Steidl, R. Haas, R. Kronenwett, Fast and reliable titration of recombinant adeno-associated virus type-2 using quantitative real-time PCR. J. Virol. Methods 106, 81-88 (2002).

41. Acknowledgments: The authors gratefully acknowledge the motivated contribution of one patient and her parents without whom this study would not have been possible. We thank K. Bushby and her group for providing the dysferlin-containing plasmid; P. Mc Neil and K. Miyake for their help in membrane repair assays; V. Delague and M. G. Mattei for constructive comments and remarks; and A. Borges and D. Bonin for technical assistance. Funding: This work was supported by grants from the Association Française contre les Myopathies (to N.W. and N.L.), the Jain Foundation (to N.L., I.R., W.L., and N.W.), Inserm (France), the Assistance Publique-Hôpitaux de Marseille (France), and the Université de la Méditerranée (France). Author contributions: C.V. and K.N. conducted clinical studies and explorations. M.K., N.W. V.L., and D.D. performed mutational and FISH analyses. N.S., F.L., and N.W. carried out histological analyses and immunoblots from patients. N.W. and S.C. performed experiments on monocytes, targeted mutagenesis, and ectopic expression experiments. M.K., M.B., N.W., and P.C. conducted cell culture-based studies. W.L., M.K., M.B., and N.B.-A. carried out animal experiments, rAAV transfer, and membrane repair assays. M.K., M.B., I.R., P.C., and N.L. were responsible for designing and supervising the project and writing the manuscript. Competing interests: The authors declare that they have no competing interests. Accession numbers: The genomic sequence of the minidysferlin is deposited in GenBank under accession number HQ222984. 